\title{
The Use of Latest Medical Technology and Taking Benefits from Technology to Treat Various Medical Diseases Including Covid-19 in the Current Pandemic
}

\author{
Ahsan Ali Siddiqui*, MD, MSPH, UK \\ Consultant Public Health, Quality Management \& Patient Safety Department, General Directorate of Health, Saudi Arabia
}

\begin{abstract}
Background and Objective: The Main Aim of this article is to highlight the advancement of Medical Technology and technique in the twenty first century. The use of Latest Medical technology to serve the ill and sick people.

Methods: The Author of this Article has done Literature Review, Comparison and Critical analysis of more than 20 Published Articles and other reviews. Author has chosen the Comparative Literature review as methodology for this research article. The purpose is to show that Randomly chosen articles are in favor to use Latest Medical Technology and taking benefits from technology to treat various medical diseases including COVID-19. SPSS 19 software is used to show Diagrammatic presentation for the results and analysis.
\end{abstract}

Results: Author of this Article has used SPSS 19 Software to present the results. First SPSS Diagram shows that All selected 15 Articles favors the Importance of the use of Latest Medical Technology and taking benefits from technology to treat various medical diseases including COVID-19 in the current Pandemic. The Second SPSS Diagram shows that 15 Articles agreed $100 \%$ for the Importance of the use of Latest Medical Technology and taking benefits from technology to treat various medical diseases including COVID-19 in the current Pandemic.

Conclusion: Latest Inventions in Science and Medical Technology are Blessing for all the Living being on this Planet Earth. From Human beings to Animals all are getting benefits to enjoy better health in twenty first century by modern treatment and surgical procedures for humans and Animals. The Human Doctor and Veterinary Doctor are getting modern medicines and technology to save the lives of their patients. Latest Medical Inventions for example Nuclear Medicine/ Nuclear scan, CT Scan, MRI Scan, Laparoscope Machine, Imaging Machine, Ultrasound, X Rays, ICU Facility with Ventilators, Endoscopy Instruments, Others are helping the Doctors and Patients to provide and receive latest Treatment for the ill and sick. Although the Advancement in Medical Technology and Sciences still a lot of Research and hard work needed as still scientists could not find the appropriate and proven treatment and Vaccine of COVID-19.

KEYWORDS: ACE inhibitors; ARBs; Actemra;Advil; HIV; Kaletra; Kevzara; Motrin; NSAIDs; Plaquenil; Tylenol; Acetaminophen; Adverse effects; Angiotensin receptor blockers; Antiretrovirals; Azithromycin; Chloroquine; Coronavirus; Corticosteroids; Hydroxychloroquine; Ibuprofen; Lopinavir; Oseltamivir; Remdesivir; Ribavirin; Ritonavir; Sarilumab; Tocilizumab; Dengue; Silymarin; Liver function tests

Quick Response Code:

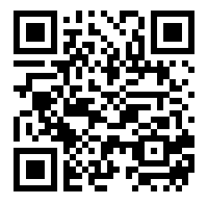

Address for correspondence: Ahsan Ali Siddiqui, MD, MSPH, UK, Consultant Public Health, Quality Management \& Patient Safety Department, General Directorate of Health, Saudi Arabia

Received: June 18, 2020 Published: July 02, 2020

How to cite this article: Ahsan Ali Siddiqui, MD, MSPH, UK. The Use of Latest Medical Technology and Taking Benefits from Technology to Treat Various Medical Diseases Including Covid-19 in the Current Pandemic. 2020 - 2(4) OAJBS.ID.000185. DOI: 10.38125/OAJBS.000185 


\section{INTRODUCTION}

WHO chose an experimental Kupferschmidt [1] antiviral called remdesivir the malaria medication chloroquine or its chemical cousin hydroxychloroquine a combination of the HIV drugs lopinavir and ritonavir and that combination plus interferon-beta an immune system messenger that can help cripple viruses? The treatments would stop the virus by different mechanisms, but each has drawbacks. Remdesivir developed by Gilead Sciences to combat Ebola and related viruses shuts down viral Kupferschmidt [1] replication by inhibiting a key viral enzyme the RNA polymerase.

Recently the Dutch Jeroen [2] National Institute for Public Health and the Environment published treatment options for antiviral treatment for COVID-19 where chloroquine was suggested as first choice for off-label treatment beside remdesivir lopinavir/ ritonavir. In this commentary we provide a background and history of chloroquine the evidence for antiviral efficacy of chloroquine and the arguments for off-label use of Jeroen [2] chloroquine in COVID-19. Current Pandemic of COVID-19 Siddiqui [3] has taught us that we in the twenty first century is not ready to provide health care to vulnerable community such as elders children and sick people with chronic illness. Such vulnerable people with bad health and low socio-economic status are more prone to get effected by COVID-19 novel corona virus. More serious work needed to be done by Global health agencies and world organizations such as WHO, CDC, UN, UNESCO, UNHCR others. Governments and health departments has to make useful health policies to implement in deadlines with serious accountability Siddiqui [3] to fight against any Epidemic or Pandemic (Figure1).
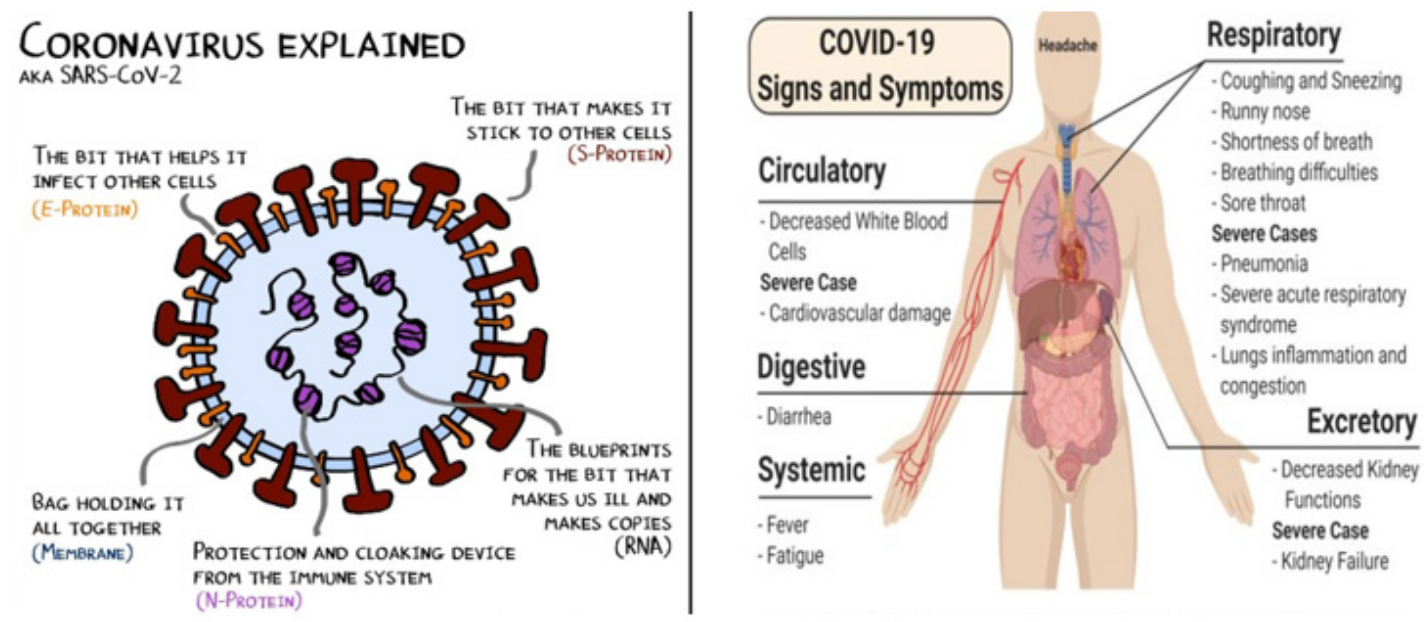

Figure 1: COVID-19 virus [38].

Despite the urgent need to find Serap [4] an effective antiviral treatment for COVID-19 through randomized controlled studies certain agents are being used all over the world based on either in-vitro or extrapolated evidence or observational studies. The most frequently used agents both in Turkey and all over the world including chloroquine hydroxychloroquine lopinavir/ritonavir favipiravir and remdesivir will be reviewed here. Nitazoxanide and ivermectin were also included in this review as they have recently been reported to have an activity against SARS-CoV-2 in vitro and are licensed for the Serap [4] treatment of some other human infections.

The objective is to investigate Ahsan [5] and find out after reviewing 23 referenced News articles and published papers to gather evidence that novel corona virus COVID-19 was accidentally leaked in the community. Eight Published Newspaper Articles were carefully selected to find out the documentary and visual evidence that novel corona virus COVID-19 was accidentally leaked from the Wuhan research Laboratory in China. Upon reviewing the carefully selected 8 News Articles only two articles provide the picture and documented evidence that may be accidentally in the Wuhan laboratory the studied novel Ahsan [5] corona virus got out of laboratory.

Global Health and other organizations A Siddiqui [6] such as WHO, UNHCR, UN, UNESCO, UNICEF did not act fast to Prevent and Control the COVID-19 Pandemic. Other Governments of the countries in the world act very slowly for the warnings given by WHO and other scientists. Later since November 2019 till now approximately 350,000 people have lost their lives due to COVID-19 and approximately 5 Million people are infected by this COVID-19 disease. The vaccine of COVID-19 is under development and there is not exact A Siddiqui [6] treatment for COVID-19 by medical sciences till now (Figure 2).

A cross-sectional study was carried Sarfraz [7] out in the OPDOut Patient Department of a secondary care hospital of Karachi among patients with self-reported history of hypertension and on anti-hypertensive medication. A total of 292 patients aged 18 or above were included in the study by convenient sampling for the duration of 6 months from January 2018 till July 2018. A randomized controlled trial was Momin [8] conducted Ziauddin hospital Clifton Karachi. The laboratory parameters utilized to measure liver function were serum levels of direct and indirect bilirubin alanine amino transferase gamma glutamyl transferase and alkaline phosphatase. Furthermore, symptomatologic improvement with Momin [8] the treatment of Silymarin in dengue patients could not be established.

To compare the clinical Imtiaz [9] signs and symptoms of dengue across gender and age-based groups. The study results showed that rash $\mathrm{p}=0.047$ and infected conjunctiva $\mathrm{p}=0.013$ were significantly associated with gender of the patients whereas nausea and vomiting $(\mathrm{p}=0.01)$, headache $(\mathrm{p}=0.016)$, retro-orbital pain $(\mathrm{p}=0.049)$ and 
infected conjunctiva $(\mathrm{p}=0.032)$ were significantly associated with Imtiaz [9] age of the patients. Data was collected using Reena [10] non-probability convenient sampling technique after taking informed consent from 316 patients diagnosed as having cancer on histopathology undergoing treatment with chemotherapeutic agent. There was no significant Reena [10] difference in occurrence of febrile neutropenia between two genders.
This study predicted that Khurram [11] there is difference in electrolyte levels before and after chemotherapy in cancer patients. This can prevent secondary impairment in cancer patients already undergoing chemotherapy. The total duration for which chemotherapy was given to patients was $5.98 \pm 2.36$ days. The levels of sodium after chemotherapy Khurram [11] with its duration showed no significant correlation $p$-value $=0.570, r=-0.036$.

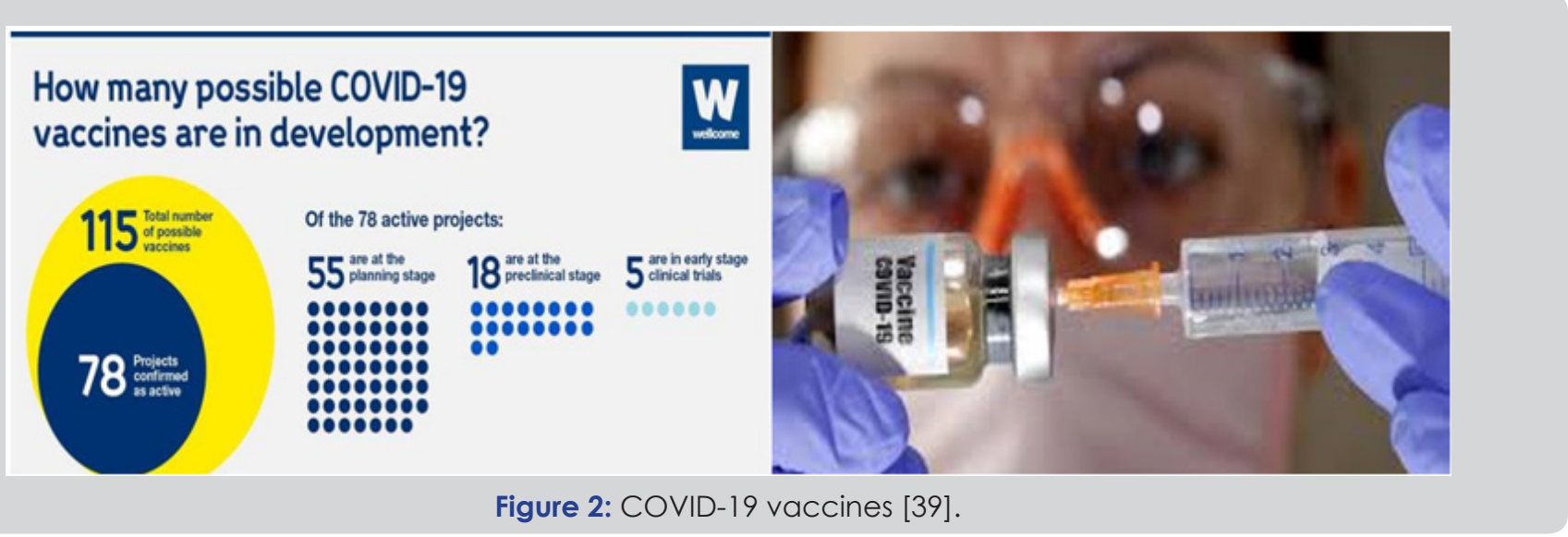

\section{METHODS}

The Author of this Article has done Literature Review, Comparison and Critical analysis of more than 25 Published Articles and other reviews. Author has chosen the Comparative Literature review as methodology for this research article. The purpose is to show that Randomly chosen articles are in favor to use Latest Medical Technology and taking benefits from technology to treat various medical diseases including COVID-19. SPSS 19 software is used to show Diagrammatic presentation for the results and analysis (Table 1).

Table 1: 15 Selected articles to show the importance of use of Latest Medical Technology and taking benefits from technology to treat various medical diseases including COVID-19.

\begin{tabular}{|c|c|c|c|c|}
\hline S.NO & $\begin{array}{l}\text { Complete Reference of the Articles } \\
\text { selected for study }\end{array}$ & $\begin{array}{l}\text { Study Favours the } \\
\text { Importance of use } \\
\text { of Latest Medical } \\
\text { Technology and } \\
\text { Taking Benefits from } \\
\text { Technology to Treat } \\
\text { Various Medical } \\
\text { Diseases Including } \\
\text { COVID-19-YES }\end{array}$ & $\begin{array}{l}\text { Study Ignores the } \\
\text { Importance of Use } \\
\text { of Latest Medical } \\
\text { Technology and } \\
\text { Taking Benefits from } \\
\text { Technology to Treat } \\
\text { Various Medical } \\
\text { Diseases Including } \\
\text { COVID-19-No }\end{array}$ & $\begin{array}{l}\text { Percentages \% of } \\
\text { Articles agreed the } \\
\text { Importance of use } \\
\text { of Latest Medical } \\
\text { Technology and } \\
\text { Taking Benefits from } \\
\text { Technology to Treat } \\
\text { Various Medical Diseases } \\
\text { Including COVID-19. }\end{array}$ \\
\hline 1 & $\begin{array}{l}\text { Serap Y, Serhat Ü (2020) Antiviral Treatment of } \\
\text { COVID-19. Turkish Journal of Medical Sciences } \\
\text { 50(SI-1): 611-619. }\end{array}$ & YES & ------- & $100 \%$ \\
\hline 2 & $\begin{array}{l}\text { Jeroen C, Peter V (2020) Chloroquine as a } \\
\text { possible treatment for COVID-19. Nederland's } \\
\text { Tijdschr Geneeskd 164: D4936. }\end{array}$ & YES & ------. & $100 \%$ \\
\hline 3 & $\begin{array}{l}\text { Kai K, Jon C (2020) Race to find COVID-19 } \\
\text { treatments accelerates. SCIENCE New York NYC } \\
367(6485): 1412-1413 .\end{array}$ & YES & ------- & $100 \%$ \\
\hline 4 & $\begin{array}{l}\text { Ahsan AS (2020) The Epidemiology of } \\
\text { COVID-19 Novel Corona Virus to Possibly } \\
\text { Control the Disease and Other Factors Relating } \\
\text { to Health Around the World. Open Acc J Bio Sci } \\
\text { 2(2): 330-337 }\end{array}$ & YES & ------- & $100 \%$ \\
\hline 5 & $\begin{array}{l}\text { Ahsan AS (2020) True or not? Chinese } \\
\text { government quotes WHO Chief statement } \\
\text { "that there is no Evidence that the New } \\
\text { Coronavirus Novel COVID } 19 \text { was Produced in } \\
\text { the Laboratory" But US Government Says, "that } \\
\text { the Coronavirus Originated from a Laboratory } \\
\text { in China despite the Lack of Evidence". Biomed J } \\
\text { Sci \& Tech Res 27(5). }\end{array}$ & YES & ------- & $100 \%$ \\
\hline
\end{tabular}




\begin{tabular}{|c|c|c|c|c|}
\hline 6. & $\begin{array}{l}\text { Adetunji H, Pinto LM, Siddique A, Samuel } \\
\text { S (2009) Potential occupational health } \\
\text { risk from exposure to nano-scale particles } \\
\text { from photocopiers - a pilot study. Revue } \\
\text { Internationale sur l'Ingénierie des Risques } \\
\text { Industriels. 2(1): 15-27. }\end{array}$ & YES & ------ & $100 \%$ \\
\hline 7 & $\begin{array}{l}\text { Sarfraz Md, Shaikh S, Zaidi SA, Raees A, Siddiqui } \\
\text { AA, et al. (2018) Blood pressure levels and } \\
\text { urinary frequency in hypertensive patients: } \\
\text { a cross-sectional analysis. J Palliative Care } \\
\text { Medicine 8: } 345 .\end{array}$ & YES & ------ & $100 \%$ \\
\hline 8 & $\begin{array}{l}\text { Momin A, Samina B, Uzma G. Ahsan AS (2018) } \\
\text { Management of dengue infection; a prospective } \\
\text { study highlighting the effect of silymarin on } \\
\text { liver functions test. Palliat Med Care 5(4): 1-7. }\end{array}$ & YES & ------- & $100 \%$ \\
\hline 9 & $\begin{array}{c}\text { Momin A, Anwar A, Imtiaz M, Siddiqui AA } \\
\text { (2019) Gender and age-based evaluation of } \\
\text { clinical signs and symptoms of dengue: A } \\
\text { secondary data analysis. SOJ Microbiol Infect } \\
\text { Dis 6(1): 1-4. }\end{array}$ & YES & ------- & $100 \%$ \\
\hline 10 & $\begin{array}{l}\text { Reena P, Ali J, Ahsan Ali S, Nasir M (2018) } \\
\text { Febrile Neutropenia in Patients Receiving } \\
\text { Chemotherapy, an observational study } \\
\text { highlighting its association with hematological } \\
\text { parameters on gender basis. Cancer Sci Res } \\
\text { Open Access 5(1): 1-5. }\end{array}$ & YES & ------- & $100 \%$ \\
\hline 11 & $\begin{array}{c}\text { Reena K, Ahsan AS, Khurram Z Zubair T (2018) } \\
\text { Correlation of Duration of Chemotherapy with } \\
\text { Electrolytes in Cancer Patients: A Prospective } \\
\text { Study Assessing the Relationship with Various } \\
\text { Electrolytes. Cancer Sci Res Open Access. 5(2): } \\
1-4 .\end{array}$ & YES & ------- & $100 \%$ \\
\hline 12 & $\begin{array}{l}\text { Siddiqui A (2018) Tuberculosis in adults in } \\
\text { Pakistan: Its epidemiology, preventive measures } \\
\text { and current legislation. Journal of American } \\
\text { Academic Research. 6(3): 33-38. }\end{array}$ & YES & ------- & $100 \%$ \\
\hline 13 & $\begin{array}{c}\text { Ahsan AS (2018) The global threat of bird } \\
\text { (Avian) flu its treatment methods and public } \\
\text { health preventive measures. SOJ Vet Sci } 4(3) \text { : } \\
1-4 \text {. }\end{array}$ & YES & ------- & $100 \%$ \\
\hline 14 & $\begin{array}{l}\text { Jamali Z, Siddiqui AA, Jamali D, Nazim S (2018) } \\
\text { Correlation of early and late cord clamping time } \\
\text { with hematological variables: an observation } \\
\text { study focusing on the neonatal outcomes. SOJ } \\
\text { Gynecol Obstet Women's Health 4(1): 1-5. }\end{array}$ & YES & ------- & $100 \%$ \\
\hline 15 & $\begin{array}{l}\text { Amna MB, Siddiqui AA, Wajid Z (2018) } \\
\text { Presentations in patients of chronic myeloid } \\
\text { leukemia an observational study focusing on } \\
\text { the association of hematological parameter on } \\
\text { gender. Cancer Sci Res Open Access 5(1): 1-5. }\end{array}$ & YES & ------- & $100 \%$ \\
\hline
\end{tabular}

Recently the increased TB Siddiqui [12] morbidity and mortality have placed additional pressure to act on state and local TB control programs which already had been substantially weakened by inadequate staffing and funding support. Treatment Muhammad [13] success rate of $67.8 \%$ among new and retreatment PTB patients and 69\% in new smear positive PTB patients was observed. Sputum positivity at 2 months AOR 13.78; 95\% CI 5.09-37.26 was a significant predictor of poor treatment outcomes in new smear positive PTB patients. The treatment success rate among PTB patients was lower than the recommended $85 \%$ success rate. TB patients at higher risk of unsuccessful treatment outcomes should be provided with enhanced supervision and treatment monitoring to improve the Muhammad [13] success rate of TB management in

\section{Pakistan.}

This essay has explored the Ahsan [14] Avian-bird flu in terms of definition classification signs and symptoms caused by Avian flu statistics of morbidity and mortality. I also discuss the some of the actions taken by the UK government to prevent the population of the UK from harmful effects of the Avian flu. This essay tells the dangers and the harmful effects done by the Avian flu and how this deadly disease spread in the communities silently and the health departments. When it comes to know about this disease how it kills the innocent people Ahsan [14] and terrorizes the whole community by its deadly results Measure and statistical Analysis: IBM SPSS Software USA [15]; (Figure 3); (Figure 4). 


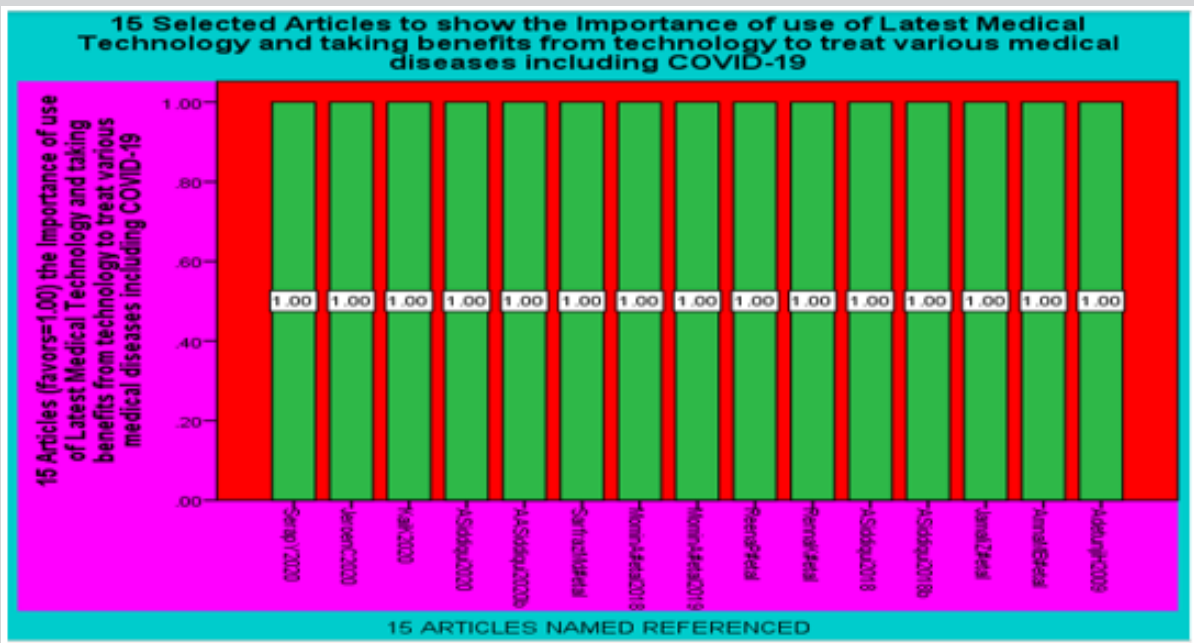

Figure 3

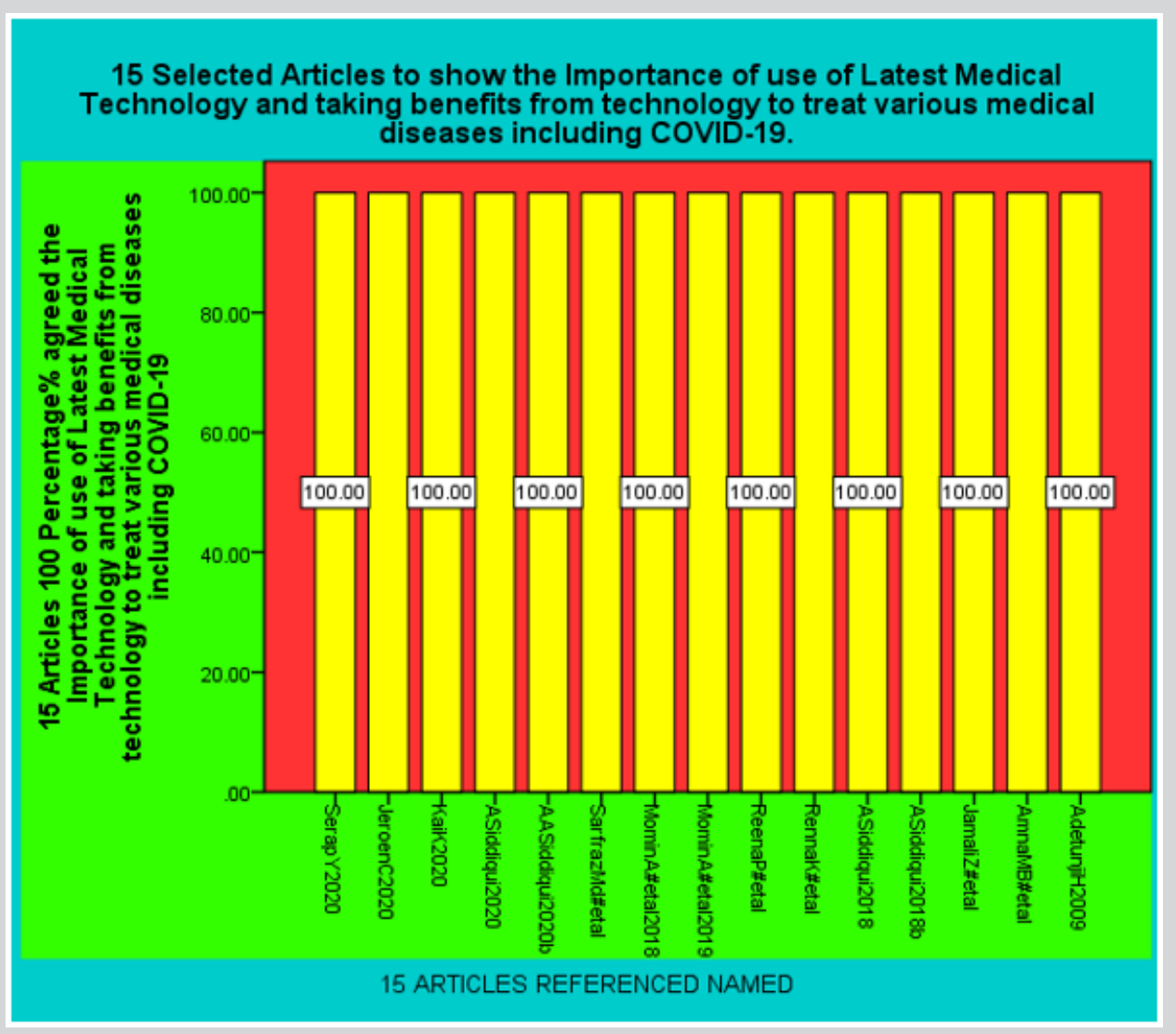

Figure 4

\section{RESULTS}

Author of this Article has used SPSS 19 Software to present the results. First SPSS Diagram shows that All selected 15 Articles favors the Importance of the use of Latest Medical Technology and taking benefits from technology to treat various medical diseases including COVID-19 in the current Pandemic. The Second SPSS Diagram shows that 15 Articles agreed $100 \%$ for the Importance of the use of Latest Medical Technology and taking benefits from technology to treat various medical diseases including COVID-19 in the current Pandemic.
Obstructive sleep John [16] apnea is more prevalent in patients with hypertension than in the general population and many with obstructive sleep apnea also have hypertension. Obstructive sleep apnea increases the risk of hypertension-related morbidities such as stroke heart failure and premature death. Are such associations coincidental or causal and if the latter what are their implications for clinical practice? Despite compelling epidemiological and mechanistic links between obstructive sleep apnea and hypertension the effect in clinical trials of the treatment of obstructive sleep apnea on John [16] blood pressure has been modest and variable. The study results revealed a positive association between longer 
duration of hypertension and presence of sleep Anwar [17] apnea albeit only before controlling for the potential confounding effects of age.

To assess the Momin [18] correlation of temperature with platelet count and total leukocyte count in patients of dengue fever. In patients with fever duration of 5 to 7 days it was significantly negatively correlated with platelet count on day 3 only $(p=0.002)$ whereas in patients aged 40 years or above it was significantly negatively correlated Momin [18] with total leukocyte count on day 3 only ( $p=0.025$ ). According to our study no Jamali [19] correlation exists between hemoglobin and hematocrit with cord clamping time, but weak positive correlation was observed between bilirubin levels with clamping time in seconds.

To determine the Natasha [9] association of neurological symptoms with blood pressure levels in hypertensive patients. Vertigo and confusion were signifiาcantly associated with higher systolic blood pressure level whereas none of them were significantly associated with diastolic blood pressure level. Moreover, the binary logistic regression analysis showed that after controlling for the confounding effects of other neurological symptoms only confusion was significantly associated with systolic blood pressure level whereas none of the neurological symptoms studied was significantly Natasha [9] associated with diastolic blood pressure level.
Hypertension has been Cinzia [20] identified as one of the most important factors of chronic transformation of episodic migraine and increases the cerebrovascular and cardiovascular risk of migraine patients. Migraine and arterial hypertension may share common mechanisms like endothelial dysfunction deficiency of autonomic cardiovascular regulation and renin angiotensin system involvement. Preventive effects of migraine were described by several antihypertensive agents traditionally beta-blockers and more recently Cinzia [20] angiotensin-converting-enzyme inhibitors and angiotensin II receptor blockers.

\section{DISCUSSION}

The present study predicted Jamali [21] that no correlation in either group existed between hemoglobin hematocrit and bilirubin with increasing cord clamping time. Group 1 had clamping time of $45 \pm 7.92$ seconds and group 2 with clamping time of $118 \pm 33.26$ seconds. Hemoglobin was $13.29 \pm 1.33 \mathrm{mg} / \mathrm{dl}$ in group 1 and $13.43 \pm 1.06$ in group 2. Hematocrit was $40.87 \pm 3.78 \%$ and $41.36 \pm 3.02 \%$ in group 1 and 2 respectively. Bilirubin (mg/dl) was $9.15 \pm 5.77$ in group 1 while $13.14 \pm 10.14$ in group 2 . Anemia was present in $7.1 \%$ and $2.9 \%$ of infants in group 1 and respectively. High bilirubin was seen in $4.1 \%$ and $19.4 \%$ Jamali [21] infants of group 1 and 2 respectively (Figure 5).

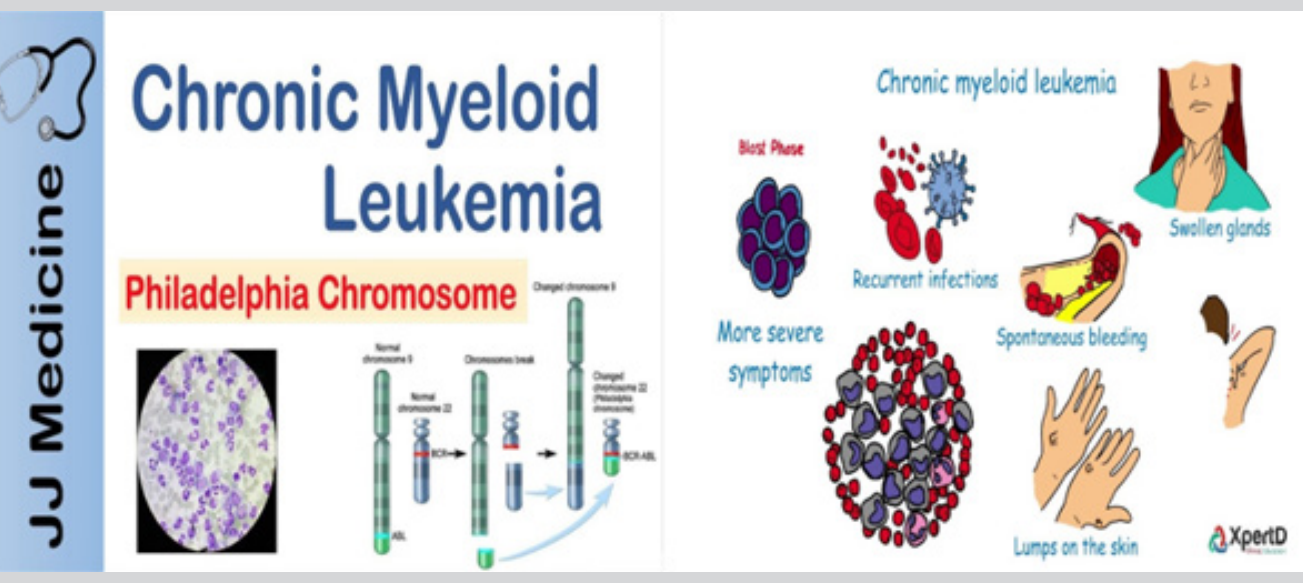

Figure 5: Chronic myeloid leukemia [41].

Despite vast improvements in treatment Elias [22] of Philadelphia chromosome-positive chronic myeloid leukemia-CML in chronic phase CP advanced stages of CML accelerated phase or blast crisis, remain notoriously difficult to treat. Treatments that are highly effective against CML-CP produce disappointing results against advanced disease. Therefore, a primary goal of therapy should be to maintain patients in CP for as long as possible by striving for deep early molecular response to treatment using tyrosine kinase inhibitors that lower risk of disease progression and Elias [22] more closely observing patients who demonstrate cytogenetic risk factors at diagnosis or during treatment. The present study predicted Amna [23] that considerable difference did not exist in various hematological parameters of male and female CML patients. However, myelocyte count (\%) in males and females was $13.87 \pm 7.49$ and 12.50 whilst $18.65 \pm 7.49$ and 18.0 respectively.

Treatment related diarrhea Dang [24] is one of the most common and troublesome adverse effects related to chemotherapy or radiotherapy in people with cancer. Its reported incidence has been as high as $50 \%$ to $80 \%$. Severe treatment-related diarrhea can lead to fluid and electrolyte losses and nutritional deficiencies and could adversely affect quality of life-QoL. It is also associated with increased risk of infection in people with neutropenia due to anticancer therapy and often leads to treatment Dang [24] delays dose reductions or treatment discontinuation. Probiotics may be effective in preventing or treating chemotherapy- or radiotherapyinduced diarrhea. Our study demonstrates Reena [25] that electrolyte imbalances are common during chemotherapy and monitoring should be done by medical oncologist so to avoid future morbidity and mortality.

The present study predicted the Shahzain [26] median age of 40.29 years in patients suffering from chronic myeloid leukemia. TLC was observed to be $228.7 \pm 152.3 \times 103$ cells $/ \mathrm{mm} 3$ though platelet count was $466.9 \pm 305.09 \times 103$ cells $/ \mathrm{mm} 3$. Moreover, no correlation existed between age and various hematological parameters in these patients. The frontline management of chronic myelogenous Pavan [27] leukemia-CML imatinib has proven to be very effective in achieving high remission rates and improving prognosis. However, up to $33 \%$ of patients will not achieve optimal 
response. This has led researchers to develop new second- and third-generation tyrosine kinase inhibitors. In this article we review the mechanisms of resistance recommendations for monitoring assessment of milestones and management options for patients with Pavan [27] CML who are resistant to imatinib therapy.

Chemotherapy-induced neutropenia Yasunori [28] is a common complication in cancer treatment. We analyzed the incidence and clinical features of chemotherapy-induced neutropenia and febrile neutropenia in patients with gynecologic malignancy. During the study period, we administered over 1614 infusions 29 regimens to 291 patients. The median age of the patients was 60 years range 24-84 years. Chemotherapy-induced neutropenia occurred in 147 (50.5\%) patients over 378 (23.4\%) chemotherapy cycles. Yasunori [28] Febrile neutropenia occurred in 20 (6.9\%) patients over $25(1.5 \%)$ cycles. The mean duration of neutropenia and fever was 3.6 days range 1-12 days and 3.4 days range 1-9 days respectively. Our study showed that significant difference exists in some of the hematological parameters including hemoglobin levels platelet count total leukocyte count neutrophil count monocyte count and absolute neutrophil count in patient treat with different chemotherapeutic drugs suffering from febrile neutropenia.

This research design assignment Ahsan [29] has explored the methodological issues relating to the research question about how to improve the health infrastructure and the health system in Pakistan and how to reduce the incidence of tuberculosis in adults in Karachi Pakistan. Finally, the chosen method (Diaries, Interviews with Data collection and analysis) enables me to explain the chosen Ahsan [30] research question and give the answers and the solutions of the problems. Pakistan ranks fifth amongst the highest TB burden countries and poses a rich ground for exploratory research to address the gender differences in TB cases. It is uniquely neighbored by India on the East having higher number of cases in males than in females and by Afghanistan and Omara [31] Iran on the West having higher number of cases in females than in males (Figure 6).

\begin{tabular}{|c|c|c|c|c|}
\hline Drug(s) & Typical Dosage & Length of Therapy & \multirow{3}{*}{\multicolumn{2}{|c|}{$\begin{array}{l}\text { CLASSIFICATION OF DRUGS USED IN ANTI- } \\
\text { TUBERCULOSIS TREATMENT }\end{array}$}} \\
\hline NH & 300 mg daily & 9 months & & \\
\hline INH & 900 mg twice weckly & 9 months & & \\
\hline INH & 300 mg daily & 6 months & \multirow{2}{*}{ FIRST LINE DRUGS } & \multirow{2}{*}{ SECOND LINE DRUGS } \\
\hline INH & 900 mg twice weckly & 6 months & & \\
\hline RIF & $600 \mathrm{mg}$ daily & 4 months & \multirow{6}{*}{$\begin{array}{l}{ }^{\circ} \text { ISONIAZIDE } \\
\text { ORIFAMPIN } \\
\text { O PYRAZINAMIDE } \\
{ }^{\circ} \text { ETHAMBUTOL } \\
\text { 'STREPTOMYCIN }\end{array}$} & ${ }^{\circ}$ AMIKACIN \\
\hline \multirow[t]{5}{*}{ INH-RPT } & \multirow{5}{*}{$\begin{array}{l}\text { INH-RPT weckly } \\
\text { INH: } 15 \text { mg/kg } \\
\text { rounded up to the } \\
\text { nearest } 50 \text { or } 100 \mathrm{mg} \\
900 \mathrm{mg} \text { max } \\
\text { RPT (weight based): } \\
300 \text { to } 900 \mathrm{mg} \max \end{array}$} & 3 months & & OAMINOSALICYCLICACID \\
\hline & & & & ${ }^{\circ}$ CAPREOMYCIN \\
\hline & & & & ${ }^{\circ}$ CIPROFLOXACIN \\
\hline & & & & ${ }^{\circ}$ CLOFAZIMINE \\
\hline & & & & ${ }^{\circ}$ CYCLOSERINE \\
\hline \multirow{2}{*}{\multicolumn{3}{|c|}{ 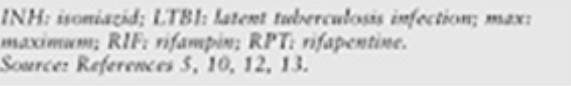 }} & & ${ }^{\circ}$ ETHIONAMIDE \\
\hline & & & & OLEVOFLOXACIN \\
\hline & & & & ${ }^{\circ}$ RIFABUTIN \\
\hline
\end{tabular}

Figure 6: Tuberculosis treatment [42].

To compare the prevalence Adnan [32] of clinical signs and symptoms of hypertension among different gender and age-based groups of hypertensive patients. Blood pressure was measured using sphygmomanometer with stethoscope. With the release Lindsey [33] of the 2017 Hypertension Clinical Guidelines 46\% of adults in the United States are now classified as hypertensive and hypertension is the primary modifiable risk factor for the development of CVD. This increase in the prevalence of hypertension is reflected in an increase in prevalence among both men and women across all demographics although there were greater increases in the prevalence of hypertension among men compared with women. As a result, the well-established gender difference in the prevalence of hypertension Lindsey [33] is even more pronounced and now extends into the sixth decade of life.

This work aimed to characterize Adetunji [34] and quantify the nanoscale particles emitted by a typical heavy-duty industrial photocopier and printer to assess the long-term effect of these particles on occupational health. The potential Adetunji [34] health risk related to toner particles is also explored. Photocopier machines Kasi [35] are inevitable office equipment but they are also sources of air pollution.

Literature Review Siddiqui [36] with Health Need Assessment and Planning - Planning Models were Applied to discuss and
Critically Analyze the NTP National Tuberculosis control program of Pakistan. They are getting also more funds and aid for NTP to Siddiqui [36] control the T.B in Pakistan. Monitoring tuberculosis treatment Zainab [37] outcomes and understanding the reasons for unsuccessful treatment are important indicators for evaluating the performance of the national tuberculosis control program. The treatment success rate among PTB patients was lower than the recommended $85 \%$ success rate. TB patients at higher risk of unsuccessful treatment outcomes should be provided with enhanced supervision and Zainab [38] treatment monitoring to improve the success rate of TB management in Pakistan [39-42].

\section{CONCLUSION}

Latest Inventions in Science and Medical Technology are Blessing for all the Living being on this Planet Earth. From Human beings to Animals all are getting benefits to enjoy better health in twenty first century by modern treatment and surgical procedures for humans and Animals. The Human Doctor and Veterinary Doctor are getting modern medicines and technology to save the lives of their patients. Latest Medical Inventions for example Nuclear Medicine/ Nuclear scan, CT Scan, MRI Scan, Laparoscope Machine, Imaging Machine, Ultrasound, X Rays, ICU Facility with Ventilators, Endoscopy Instruments, Others are helping the Doctors and Patients to provide and receive latest Treatment for the ill and sick. Although 
the Advancement in Medical Technology and Sciences still a lot of Research and hard work needed as still scientists could not find the appropriate and proven treatment and Vaccine of COVID-19.

\section{REFERENCES}

1. Kupferschmidt K, Jon C (2020) Race to find COVID-19 treatments accelerates. SCIENCE New York 367(6485): 1412-1413.

2. Jeroen C, Peter V (2020) Chloroquine as a possible treatment for COVID-19. Nederlands Tijdschr Geneeskd 164: D4936.

3. Ahsan AS (2020) The epidemiology of COVID-19 novel corona virus to possibly control the disease and other factors relating to health around the world. Open Acc J Bio Sci 2(2): 330-337.

4. Serap Y, Serhat Ü (2020) Antiviral treatment of COVID-19. Turkish Journal of Medical Sciences 50(SI-1): 611-619.

5. Ahsan AS (2020) True or not? Chinese government quotes WHO Chief statement "that there is no evidence that the new coronavirus novel COVID 19 was produced in the laboratory" But US government says, that the coronavirus originated from a laboratory in China despite the lack of evidence. Biomed J Sci \& Tech Res 27(5): 21148-21155.

6. Ahsan AS (2020) COVID-19 Pandemic and public health preventions to reduce the infection, incidence and distribution among the community. Open Acc J Bio Sci 2(2): 345-352.

7. Sarfraz Md, Shaikh S, Zaidi SA, Raees A, Siddiqui AA, et al. (2018) Blood pressure levels and urinary frequency in hypertensive patients: A crosssectional analysis. J Palliative Care Medicine 8: 345.

8. Momin A, Samina B, Uzma G, Ahsan AS (2018) Management of dengue infection: A prospective study highlighting the effect of silymarin on liver functions test. Palliat Med Care 5(4): 1-7.

9. Anwar A, Natasha M, Imtiaz M, Razia A, Zarghoona W, et al. (2019) Neurological symptoms in hypertension: Association with blood pressure levels. SOJ Neurology 6 (4):1-6.

10. Reena P, Ali J, Ahsan AS, Nasir M (2018) Febrile neutropenia in patients receiving chemotherapy, an observational study highlighting its association with hematological parameters on gender basis. Cancer Sci Res Open Access 5(1): 1-5.

11. Reena K, Ahsan AS, Khurram Z, Zubair T (2018) Correlation of duration of chemotherapy with electrolytes in cancer patients: a prospective study assessing the relationship with various electrolytes. Cancer Sci Res Open Access 5(2): 1-4.

12. Siddiqui A (2018) Tuberculosis in adults in Pakistan: Its epidemiology, preventive measures and current legislation. Journal of American Academic Research. 6(3): 33-38.

13. Muhammad A, Zainab A, Razia Fatima, Iram Malik et al. (2018) Analysis of tuberculosis treatment outcomes among pulmonary tuberculosis patients in Bahawalpur, Pakistan. BMC Research Notes. 11(1): 370.

14. Ahsan AS (2018) The global threat of bird (avian) flu its treatment methods and public health preventive measures. SOJ Vet Sci 4(3): 1-4.

15. IBM (2006) IBM SPSS Software USA.

16. John SF (2015) Hypertension and sleep apnea. The Canadian Journal of Cardiology. 31(7): 889-897.

17. Anwar A, Fatima S, Zia MK, Sohaib T, Ahsan AS, et al. (2018) Sleep apnea in hypertensive patients: relationship with duration of hypertension and the effect of age. Palliat Med Care 5(4): 1-4.

18. Momin A, Anwar A, Imtiaz M, Siddiqui AA, et al. (2019) Gender and agebased evaluation of clinical signs and symptoms of dengue: A secondary data analysis. SOJ Microbiol Infect Dis 6(1):1-4.

19. Jamali Z, Siddiqui AA, Jamali D, Nazim S (2018) Correlation of early and late cord clamping time with hematological variables: An observation study focusing on the neonatal outcomes. SOJ Gynecol Obstet Womens Health 4(1): 1-5.

20. Cinzia Finocchi, Davide Sassos (2017) Headache and arteria hypertension. Springer Link, Neurological Sciences 38(Suppl 1): 67-72.

21. Jamali Z, Fatima M, Yaqoob S, Ahsan S (2018) Neonatal outcomes in cord clamping: An observational study highlighting the correlation of cord clamping time with hematological parameters. SOJ Gynecol Obstet Womens Health 4(1): 1-5.

22. Elias J, Timothy H, Jorge C, Hagop K (2014) Potential mechanisms of disease progression and management of advanced-phase chronic myeloid leukemia. Leuk Lymphoma. 2014 Jul; 55(7): 1451-1462.

23. Amna MB, Ahsan AS, Shahzain H, Mir A (2018) Characteristics of chronic myeloid leukemia: an observational study highlighting the correlation of age with hematological parameters. Cancer Sci Res Open Access 5(1): 1-4.

24. Dang W, Pauline H, Fleur W Geertjan T, et al (2018) Probiotics for the prevention or treatment of chemotherapy- or radiotherapy-related diarrhoea in people with cancer. Cochrane Database Syst Rev 2018(8): CD008831.

25. Reena K, Ali SA, Zubair T, Fatima S, (2018) Levels of electrolyte in cancer patients; a prospective study focusing on the variations before and after therapy. Palliat Med Care 5(4): 1-4.

26. Reena K, Ahsan Ali S, Shahzain H (2018) Chemotherapy in different cancers; an observational study highlighting the association of febrile neutropenia with various hematological parameters. Palliat Med Care 5(3): 1-4.

27. Pavan B, Hagop K, Jorge C, Cornelison A (2013) Management of imatinibresistant patients with chronic myeloid leukemia. Ther Adv Hematol 4(2): 103-117.

28. Yasunori H, Mari K, Takeshi F, Tomoyuki I (2015) Chemotherapy-induced neutropenia and febrile neutropenia in patients with gynecologic malignancy. Anticancer Drugs 26(10): 1054-1060.

29. Ahsan S (2018) How to efficiently reduce the incidence of tuberculosis (TB) disease in adults in Karachi Pakistan. Journal of American Academic Research 6(3): 45-49.

30. Siddiqui A (2018) Critically review and evaluate national tuberculosis control program (NTP) of Pakistan. Journal of American Academic Research. 6(3): 28-32.

31. Omara D, Sarwat S, Abrar C, Ejaz Q (2012) Gender disparity in tuberculosis cases in eastern and western provinces of Pakistan. BMC Infect Dis 12: 244

32. Adnan A, Hafsa K, Ahsan AS, Somaiya I, Zarghoona W, et al. (2018) Prevalence of clinical signs and symptoms of hypertension: A gender and age-based comparison. Palliative Med Care 5(2): 1-8.

33. Lindsey R, Jennifer S (2018) Sex differences in hypertension: where we have been and where we are going. Am J Hypertens 31(12): 1247-1254.

34. Adetunji H, Pinto LM, Siddique A, Samuel S (2009) Potential occupational health risk from exposure to nano-scale particles from photocopiers: A pilot study. Revue Internationale sur l'Ingénierie des Risques Industriels 2(1): $15-27$

35. Kasi V, Elango N, Ananth S, Vembhu B (2018) Occupational exposure to photocopiers and their toners cause genotoxicity. Human and Experimental Toxicology 37(2): 205-217.

36. Amna MB, Siddiqui AA, Wajid Z (2018) Presentations in patients of chronic myeloid leukemia; an observational study focusing on the association of haematological parameter on gender. Cancer Sci Res Open Access 5(1): 1-5.

37. Muhammad A, Zainab A, Razia F, Iram M (2018) Analysis of tuberculosis treatment outcomes among pulmonary tuberculosis patients in Bahawalpur, Pakistan. BMC Res Notes 11: 370

38. Google images (2020) COVID-19 virus.

39. Google images (2020) COVID-19 vaccines.

40. Momin A, wajid Z, Adil M, Haleem F, Siddiqui A (2019) Correlation of temperature with platelet count and total leukocyte count in dengue: findings from a secondary data analysis. SOJ Microbiol Infect Dis 6(1): $1-4$.

41. Google images (2020) chronic myeloid leukemia.

42. Google image (2020) Tuberculosis treatment. 